\title{
Kids, the academic library,
}

\section{and the schools}

\author{
By Carol Burroughs Hammond \\ Head, Information and Research Support Services \\ Arizona State University West Campus
}

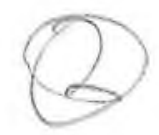

Arizona State University West Campus

\section{A model for partnership.}

A rizona State University West Campus Library is part of a new branch campus, and is still in the evolutionary process of developing policies. A recent experience with a local elementary school helped us develop a different perspective toward school children in the library, and motivated the development of a partnership with school librarians to reduce problem behavior among younger children who come to the library. We have used the same model to help improve our interaction with high school students.

ASU West is a newly established institution which is presently under construction in northwest Phoenix. The campus covers 300 acres, encompassing several city blocks of partially developed property surrounded by a suburban residential area. The campus provides a park-like environment for many of the local area residents; the perimeter is landscaped and includes several miles of paved walking and jogging paths. Much of the interior is the natural desert landscape, complete with jackrabbits and roadrunners. ASU West, situated as it is with shopping, schools, and homes nearby, attracts community members of all ages who arrive on campus by bicycle, skateboard, or on foot in addition to the usual automobile. The new campus has been especially attractive to school children, since it borders on the playground of an elementary school.

The library at ASU West is the first building to be constructed, completed, dedicated, and open for business. The library is not only the first structure on the campus open to the public as well as students and faculty, but is a state-of-the-art electronic facility which has drawn a good deal of attention from educators at all levels. The library, because of both its newness and its electronic orientation, has generated a great deal of interest statewide as well as nationally, but especially on the west side of Phoenix. It plays host to many visitors, in both formal and informal situations. After a festive opening day, as the staff began to deal with the public, we found some visitors were more welcome than others because some were simply not good guests. This bothersome category of callers was local area school children who came after school and on weekends to skateboard, run through the building, play with the online catalog and other computers, make calls from one pay phone in the building to another to hear them ring, and otherwise exhibit behavior that was not conducive to concentration, study, reading, or research. Staff found themselves trying to control curious, noisy, misbehaving children all over the building. At one point, additional security officers were hired to help library staff control children in the facility. Our objective was to discourage them from coming to the library where, unsupervised by teachers or parents, they became disruptive.

In the midst of this unhappy situation, we re- 
ceived a call from the assistant principal of the nearby elementary school, who wanted to arrange a tour of the library for the fifth grade students. One of the teachers had visited the campus and thought it would be a wonderful opportunity for the children to see "all the computers" and to visit an academic library, especially one which they had watched through all the phases of construction from ground-breaking to dedication. With the staff already spending almost more time policing children than in providing information services for users, one of our last interests was to invite more school children to the building. Additionally, the design of our collections and service program made the library especially inappropriate for use by youngsters. As a brand-new institution, our collection is highly selective and is planned to support only the needs of a graduate and upper-level curriculum in specific disciplines. We rely heavily on access to and delivery of resources from the Tempe campus, a service which is not available to nonstudents under 21 years of age. In fact, those under 21 are not eligible for borrowing privileges. Our periodical holdings are largely on microfiche. And since the library opened, the staff was extremely busy teaching students how to use an electronic library which uses a non-traditional model for delivery of services. Besides, almost all of the children who had come to the library so far had only caused behavior problems both inside and outside the building, and everything we did was aimed at discouraging this group from coming anywhere near the campus. This was the message I conveyed to the caller.

The assistant principal invited me to consider an alternative approach to our problem which she believed would correct some of the behavior problems we had experienced. If we would provide a tour for the fifth-graders, we could deliver a positive message to the children about what goes on in an academic library, and why a quiet environment is important to the students of the University who are its primary users. We could explain what the computers are for and why they aren't toys, and we could tell them why they should come with their parents if they wanted to use this particular library. She suggested that once their curiosity about what was here was satisfied, we would see fewer unattended children in the building. She convinced me that if we would give them the opportunity to visit the library, we could stand to benefit considerably ourselves by solving some of our problems with local children. We agreed to schedule a field trip for the students, with the understanding that I would coordinate the visit with the school librarian. I explained our situation to the librarian who understood the limitations of our library for fifth-grade students, and who arranged to visit the class the day before the trip and give a talk to them about college-level study and the difference between their library and ours. The assistant principal planned to talk to them about behavior.
Some twenty students along with their teacher, school librarian, and assistant principal arrived for their tour, which was handled by two library paraprofessionals. Before the tour began, the library assistants talked about the need for a quiet environment in this library, and explained why children should come with their parents if they wanted to use the library. In addition to a walking tour of the building, they gave demonstrations of the online catalog, a CD-ROM index, our National Gallery of Art laser disk, and microfiche readers. The children were quiet, the tour went well, but we didn't realize how well until we received letters from the students a few days later.

We found we had served as recruiters, when one student wrote: "When I grow up and go to college I want to go there to ASU West," and another said: "I can't wait until 1996, which is when I will be going to college. That is probably when you have retired or quit, but I hope there will be teachers as nice as you." They were impressed with technology, and may be the only group of users we have encountered who seem to like microfiche. They wrote: "My favorite things were your CD player and the microfische," and "I am amazed at the stuff you have there. I didn't know that you have microfische." There was evidence that we would see an improvement in behavior from letters which said, "We mostly thank you for trusting us," and from this confession: "I'm sorry for all the people who have been riding their skateboards up to the library. I'm one of them. I am sorry for what I did." Finally, we heard from a traditionalist: "The four things that I liked were the computers, the data disks, and the newspaper copier. But the one thing I liked most of all was the books."

To work toward a more positive and workable relationship with both elementary and secondary school students who come to the library, we have taken a pro-active stance in establishing a program of working through the school librarians in our area to educate the teachers they work with about the limitations and the possibilities of using the ASU West Campus library. We have invited the school librarians from each district to come to our campus for a library tour. We have held discussions at these sessions about how we can work together to handle the library needs of their students. When we receive requests for tours or from teachers who want to bring classes, we require that they have a session with their school librarian before they come. We ask the librarians to provide basic instruction, such as how to read LC call numbers, and to explain some of our policies. When high school students or classes arrive without making prior arrangements, we contact the school librarian and ask him or her to encourage the faculty member to plan future visits ahead of time, and only come when the assignment is appropriate to our collection and students have some instruction in how to use our library. Elementary school librarians are asked to stress appropriate behavior. 
We have already seen encouraging and positive results from our partnership approach to serving those young library users who may be our future students.
The author wishes to acknowledge the contributions to this article made by the fifth-grade students and the administration of Sweetwater School in Glendale, Arizona.

\section{Als elections \\ ALA candidates on ACRL}

\section{The four candidates for ALA president share their views on academic and research librarianship.}

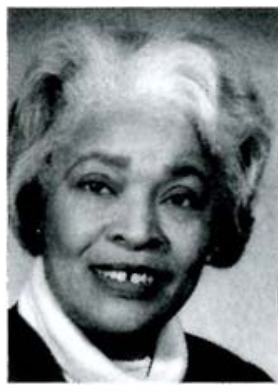

Rebecca T. Bingham

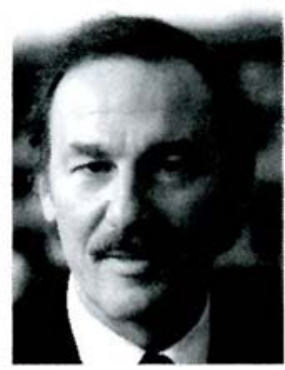

Richard M. Dougherty

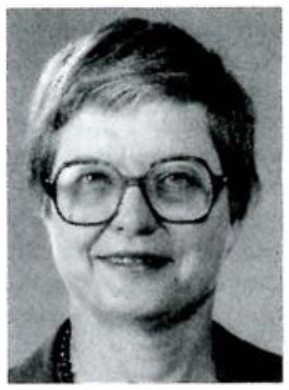

Irene B. Hoadley

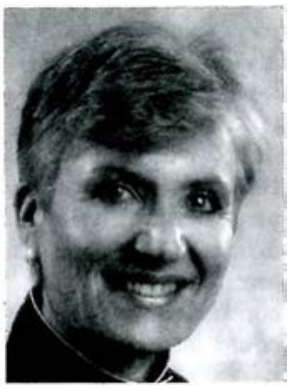

Hannelore B. Rader

$\mathbf{R}$ ecently the ALA presidential candidates were asked to give some thought to ALA/ACRL relations and academic librarianship in general for this special C\&RL News feature. Their statements may aid you when you vote for ALA officers on this spring's ballot.

\section{Rebecca T. Bingham:}

I have long admired the leadership role of ACRL, ALA's largest, financially strongest unit. I believe that the goal of any professional association

is to enhance the profession it represents and the talents and abilities of its members. By this measure, ACRL's record is outstanding. It has not only provided a model of standards, long-range planning and effective use of the chapter system for ALA, but ACRL has played a strong leadership role in ALA through the service of its members and officers on Council, in the units, on the committees, and on the round tables.

At the risk of sounding dramatic, I can say that I have a long-standing love affair and identification with academic libraries. I attribute my being a li- 